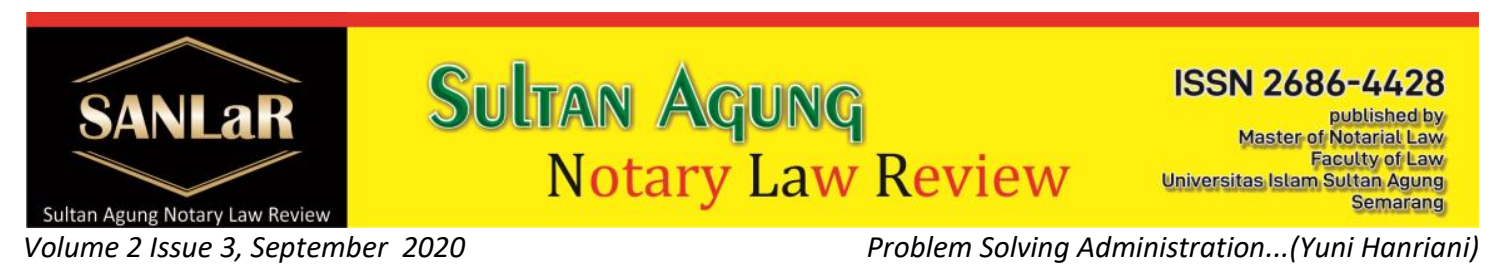

\title{
Problem Solving Administration of Notary/PPAT's Errors
}

\author{
Yuni Hanriani ${ }^{*}$ and Maryanto**) \\ *) Student of Master of Notary Law, Universitas Islam Sultan Agung (UNISSULA) \\ Semarang, E-Mail: hanriani.yuni@gmail.com \\ ${ }^{* *}$ Lecturer of Master of Notary Law, Universitas Islam Sultan Agung (UNISSULA) \\ Semarang
}

Abstract. This study was appointed because of a problem that arose at PT bank BRI Syari'ah Semarang Branch Office, where there was an error in writing the financing agreement in the explanation of the principal deed. The problem was only discovered 1 year after the signing of the notarial financing agreement and the issuance of the mortgage rights by BPN and the customer with the status of a non-performing customer so that a guarantee auction would be executed. The problems raised in this study were: (1) What were the factors that caused errors in making SKMHT ?; (2) How is the function of the Notary Regional Supervisor in resolving the Notary's mistakes in making the wrong SKMHT Notarial Deed ?; (3) How are the efforts to resolve the wrong SKMHT that has been issued by BPN, without harming the parties? The research methodology used in this research is a sociological yuiridis approach, by paying attention to conditions in the field and linking them to the prevailing laws and regulations. Based on the results of research in the field, it is known that: (1) The factors that caused errors in making a Power of Attorney to impose Mortgage Rights (SKMHT) were: negligence in writing in Minuta which resulted in imperfect binding defects on matters that had been agreed between the two parties. parties, the lack of thoroughness between the parties in further examination of the results of the writing that has been made in the form of SKMHT deeds, and is due to excessive trust in their staff; (2) The function of the notary area supervisory board in examining and resolving problems in the field, also checks the physical minimum deeds of notaries. Viewed in an ideal level, it is necessary to separate the authority of the supervisory board. namely, the supervisory panel is more appropriate to supervise the behavior of a notary in carrying out the duties of a notary public or behavior that can interfere with the performance of the notary's duties; (3) Settlement measures taken by BRI Syari'ah and the notary concerned, is that the Bank asks the notary to be accountable by conducting a Renvoi by the Notary.

Keywords: Administration; Notary; Attorney.

\section{Introduction}

The position of Notary is a public or public office because the Notary is appointed and dismissed by the government, the Notary carries out state duties, and the deed made, namely the minuta (original deed) is a state document. A public official is an official who is appointed and dismissed by the general power (government) and given the authority and obligation to serve the public in certain matters, because of that he participates in exercising government authority. 
In carrying out its duties and responsibilities, a Notary Public (PPAT) is asked to be able to act more carefully, carefully, disciplined and in accordance with the Notary Position Regulations. Moreover, the Notary profession cannot be separated from the interests of the general public and banking.

However, what if the Notary Public (PPAT), in his duties and responsibilities, makes a mistake in making the authentic deed, namely the deed to mortgage land or lend money with land rights as dependents. This problem only became known after many years and when one party was declared a "Bad Customer" by the Bank. And after the mortgage deed is registered at the local City BPN.

From these conditions, many problems have arisen, ranging from collateral execution that cannot be implemented, the existence of bank internal and external audits stating that the agreement is invalid because of the Deed of Mortgage issued by a Notary (PPAT) there is an error, not to mention from the side of the Notary who stated that settlement at BPN requires extra costs and efforts.

\section{Research Methods}

The research methodology used in this research is a sociological yuiridis approach, by paying attention to conditions in the field and linking them to the prevailing laws and regulations.

\section{Results and Discussion}

\subsection{Factors causing errors in making SKMHT}

\subsubsection{Negligence}

Negligence can be interpreted as an action taken because of a lack of caution and resulting in losses to other parties. There are various forms of negligence committed by notaries, one of which is a typo or a typo in the making of an authentic deed which because of this can result in the deed's proof value being imperfect.

If the typo (in the contents of the deed), whether substantively or non-substantive, is known before the draft deed is signed, then the error can be corrected by making amendments or Renvoi and at the initials to the left of the deed by the tappers, witnesses and notaries, as intended in Article 48 paragraph (2) and Article 50 UUJN. This initial acts as a signature so that changes to the contents of the deed without initials or other signs of validation result in the change not being binding on the person or change is considered non-existent or null and void by law.

However, if the typo was discovered only after the copy of the deed was issued, the notary could actually correct the typo. According to Article 51 paragraph (1) and paragraph (2) UUJN the correction is carried out by making a corrective official report 
and providing a note about it in the original deed by stating the date and number of the corrected official document.

The implementation of the provisions of Article 51 of the UUJN becomes difficult if:

a. The Tappers are no longer in the presence of the Notary, meaning that the Tappers have left the Notary;

b. Interactors are difficult to contact or can be contacted but do not want to come for various reasons;

c. The parties no longer want to meet face to face because there is a dispute. So that the Deed of Correction Official Report is invalid if it is done without the presence of the Facilitators and Witnesses, meaning that if the Facilitators are not willing to come forward to make the Correction Official Report, the Notary can not do anything about this so that the notary has certainty that the tappers understand and approving corrections made by a notary, besides making an official report of the corrections without before the witnesses and the presence of witnesses is a violation and the sanctions as stated in Article 51 paragraph (4) UUJN.

\subsubsection{Not careful}

In this case, based on the results of an interview with one of the notary staff, each deed that has been typed will be submitted at the Notary's desk for review, if it requires repairs before signing the Bank financing agreement. However, several notaries, did not read carefully and immediately brought the deed to be signed at the bank. And there are not a few notaries who immediately submit the deed to their staff, to be brought to the bank, without any assistance from the notary itself. In the case raised, the notary concerned does not review the typing results of his staff, he immediately signs it. Then a copy of the deed will be submitted to the Bank.

Actually, in this case all parties (notaries, customers and banks) must pay attention and be careful about what is read by the staff of the notary, not only listening, but also reviewing together what has been read. Until the reading of the SKMHT notary deed is complete, there is no rebuttal from either party, so that there is a writing error as if it was "allowed" by the parties.

Accuracy in correcting writing errors followed by reading of the deed or the agreement constitutes an entity that cannot be abandoned by interested parties. Because this is the basis so that there are no writing errors and if there are errors, they can be corrected immediately or minimize errors.

\subsubsection{Gives excessive trust}

Whereas in the Law on the Position of Notary Public, it has been clearly stated that a notarial deed must be read by a notary in the presence of witnesses. However, in 
practice, NH notaries at BRI Syari'ah Bank do not act according to the provisions of the prevailing laws and regulations.

Often the authors observe that in practice, when the notarial agreement deed is signed, the notary staff does not read out the entire contents of the deed to the parties. They generally only read out the parties 'comparisons, then ask for the original KTP to check the correctness of the parties' data. In fact, apart from reading out the parties' comparisons, the main contents of the deed should also be read, whether it is in the form of the financing agreement used, the agreed financing limit, the financing period, and the purpose of the financing, and what the customer will use the financing for.

In this case, when the notary deed was signed, the notary concerned was not attended, only represented by his staff, and because the customer was in a rush, the notary staff did not read the contents of the deed. Only from the Bank represented by the Legal Team read out the contents of the SPPP (Approval in Principle of Financing).

In the Law on Notary Position Number 2 of 2014, article 16 paragraph (1) letter m:

"In carrying out his position, the Notary is obliged to read the Deed in front of the audience in the presence of at least 2 (two) witnesses, or 4 (four) special witnesses for the making of the will under hand, and signed on the spot by the parties, witnesses and notaries. ".

If the notary does not read it according to the provisions of the law above, then the deed made by the notary only has the power of evidence as an underhand deed, as contained in article 16 paragraph (9) of the UUJN.

The theory used in the discussion of "causes of notary errors" is the theory of legal certainty. Deeds made by Notaries are in essence authentic deeds that provide legal certainty for the parties. With an error in the making of a notary, in practice, the deed made in the status of proof only has legal force as an underhand deed. In the event that a notary is a public official who has the authority to make an authentic deed that has perfect evidentiary power, the Notary deed must be made in the form prescribed by law, this is one of the characteristics of the Notary Deed. If the Notary deed has met the existing provisions, the Notary deed provides legal certainty and protection to the parties regarding the agreement they have made.

In the event that there is an error by the Notary Public in writing the contract in the Notary deed, it is imperfect the legal certainty that exists between the two parties so that it will create a norm conflict against the existing rules.

\subsection{The Participation of Notary Supervisors in Resolving Notary Errors}

Supervision of the implementation of the notary office is carried out by the minister in charge of the notary field and in the implementation of this supervision the minister 
forms a separate institution called the notary supervisory board. The supervision carried out by the assembly is not only the implementation of the duties of a notary in accordance with the provisions of the UUJN, but also according to the implementation of the notary code of ethics. Article 67 Paragraph (3) UUJN determines that the Supervisory Council shall consist of 9 (nine) persons consisting of the following elements:

a. Government as many as 3 (three) people.

b. 3 (three) notary organizations.

c. 3 (three) experts/academics. ${ }^{1}$

Supervision carried out by the Supervisory Council is not only the implementation of the duties of a Notary in order to comply with the provisions of the Law on Notary Office, but also the Notary's Code of Ethics and actions or behavior of Notaries that can injure the dignity of the Notary's office. In the supervision of the Supervisory Council (Article 67 paragraph 5 UUJN), this shows the very wide scope of supervision carried out by the Supervisory Council.

The purpose of conducting supervision of Notaries is also so that notaries can carry out their duties in accordance with the existing provisions in securing the public interest. So that the public will feel safe while using the services of a notary to make evidence in the form of an authentic deed according to the request.

The supervisory panel is also authorized to physically examine the notary office and its apparatuses, as well as to examine the physical notary deed minuta. Seen at an ideal level, it is necessary to separate the supervisory board's authority, namely the supervisory board is more appropriate to supervise the behavior of notaries in carrying out notary duties or behavior that can interfere with the implementation of notary duties, because notary behavior is guided by UUJN to have good implications. in carrying out the duties of a notary public. ${ }^{2}$ The supervisory panel does not need to supervise and examine the physical office of the notary public, because the physical condition of the notary office is minimally adjusted to the needs of the notary concerned, and there is no need to examine the minuta of deeds made by the notary concerned, because deeds are an embodiment of notary's scientific ability in carrying out his/her job duties.

\footnotetext{
${ }^{1}$ Adjie, Habib. (2006). Tidak ada sengketa kewenangan antara PPAT dengan Notaris dalam bidang pertanahan. Majalah Renvoi. p.4

${ }^{2}$ Adjie, Habib. (2015). Majelis Pengawas Notaris Sebagai Pejabat Tata Usaha Negara. Bandung: Refika Aditama. p.26
} 
In the case faced by Bank BRI Syari'ah, the supervisor who plays a very important role in this problem is the Regional Supervisory Council (MPD). Why is that, because the Regional Supervisory Council is at war to oversee the performance of Notaries in the region. In the Law Journal written by Aryani Witasari SH. M.Hum, as one of the MPD members for the Semarang Regency area, mentioned

"... MPD stands for Regional Notary Supervisory Council. This institution is formed by the Government (Minister of Law and Human Rights), domiciled in a Regency or City. MPD is the only institution authorized to supervise, inspect, examine and impose sanctions on Notaries in the Regency/City area. Above this institution are the Regional Supervisory Council and the Central Supervisory Council." ${ }^{3}$

In Act No. 2 of 2014 concerning the Position of Notary Public (UUJN), Article 66, it is clearly stated that the MPD's powers are:

a. For the purposes of the judicial process, investigators, public prosecutors, or judges with the approval of the MPD are authorized:

1) Take a photocopy of the Minutes of Words and letters attached to the Minutes of Deed or Protocol of Notaries in the storage of the Notary;

2) Calling the Notary Public to be present in the examination relating to the deed he made or the Notary's protocol that is in the Notary's storage.

b. Taking photocopies of Minuta Deeds or letters as referred to in paragraph (1) letter shall be made a Minuta of Delivery.

The theory used in the formulation of this second point is the theory of authority, where in its field practice, we see how the authority of the notary supervisory board in solving this case.

In the cases examined in this discussion material, there is no visible role of the notary supervisor in supervising the notary's performance. However, in this case what happens is the participation of the Notary Superintendent only acts when a complaint occurs. So that their participation is still not maximal in overseeing the implementation of the notary office which must be carried out by the Notary Supervisor.

\subsection{Efforts to resolve errors in SKMHT that have been issued Mortgage Rights by BPN}

Between the Power of Attorney to Charge Mortgage Rights (SKMHT) and the Deed of Granting Mortgage Rights (APHT), issued by 2 (two) notaries from 2 (two) different jurisdictions. The power of attorney to impose mortgage rights (SKMHT) was issued by

\footnotetext{
${ }^{3}$ Witasari, Aryani. (2012). MPD Bukan Advokat Para Notaris Berdasarkan Undang-Undang Nomor 30 Tahun 2004 tentang Jabatan Notaris, Jurnal Hukum Vol.XXVIII, No 2. p.2
} 
the Kendal District Notary/PPAT with the initials NH because he is a Notary Public Partner of Bank BRI Syari'ah KC Semarang. Meanwhile, the APHT is issued by the Surakarta Notary Public, because the location of the T/B assets that is guaranteed is in the Surakarta area ${ }^{4}$.

In its publication, the origin of the error in the Deed of Granting Mortgage Rights (APHT) was due to an error in writing in the SKMHT issued by Kendal's Notary Public. The financing contract that should have been contained in the Power of Attorney to Charge Mortgage Rights (SKMHT) is the IMBT contract (Ijarah Mtttahiya Bit Tamlik), but in fact what is written is the Murabahah contract. This problem was only known by the Bank 1 year after signing the contract, in which BPN Surakarta has issued HT (Mortgage Rights) in SHM owned by customers of Bank BRI Syari'ah, where the customer is in default status, and a guarantee auction will be executed at the KPKNL Surakarta.

Until the results of this study are completed, the deed has been corrected, by means of Renvoi. But after checking, the Renvoi was not accompanied by the affixing of initials, either by notaries, witnesses or tappers. This is not in accordance with the provisions in UUJN Number 2 of 2014, Article 48 paragraph (1), which reads:

a. The contents of the Deed are prohibited from being changed by:

1) Replaced;

2) Plus;

3) Crossed out;

4) Pasted;

5) Deleted; and/or

6) Written on top of it.

Changes in the contents of the Deed as referred to in paragraph (1) letter a, letter $b$, letter $c$, and letter $d$ can be carried out and are valid if the change is initialed or given other signs of approval by the parties, witnesses and notaries.

Violation of the provisions as referred to in paragraph (1) and paragraph (2) results in a deed only having the power of proof as an underhand deed and can be an excuse for the party suffering a loss to demand reimbursement of fees, compensation and interest from the Notary.

\footnotetext{
${ }^{4}$ Widyawati, \& Handoko, Widhi. (2018). The Notary Role / PPAT in Improving Legal Awareness Society to Perform Registration Rights to Land Based on Government Regulation No. 24 of 1997 on Land Registration. JURNAL AKTA: Vol. 5, No. 4, 975-980. Retrieved from http://jurnal.unissula.ac.id/index.php/akta/article/view/4127
} 
If seen from the practice of Renvoi carried out by the Notary, and seen by the provisions of the applicable laws and regulations, the Renvoi carried out by the Notary $\mathrm{NH}$, is invalid, because the first Renvoi is not accompanied by initials or thumbprints of the parties, the second is the writing of the Wakalah contract in deeds are not automatically crossed out. Even though the Wakalah contract has nothing to do with the IMBT financing contract, the Wakalah contract is an integral part of the Murabahah contract.

Meanwhile, the theory used in the discussion of the formulation of the third problem uses the theory of justice. Namely by seeing when a case occurs in the field such as the case being discussed, whether the solution can provide justice for the parties involved.

\section{Closing}

Besides that, the writing error was also caused by the lack of accuracy between the parties in further examination of the results of the writing that had been made in the form of SKMHT deeds, both notaries and the bank represented by the legal bank. This resulted in the passing of a writing error that should have been reviewed for correction. Likewise by giving excessive trust to staff or employees, so that the responsible party, in this case a notary, immediately accepts and approves the results of the deed, before checking or reviewing the results written by his staff. So that it resulted in a writing error which should have been examined more thoroughly on the contents of the deed.

\section{References}

Journal:

[1] Widyawati, \& Handoko, Widhi. (2018). The Notary Role / PPAT in Improving Legal Awareness Society to Perform Registration Rights to Land Based on Government Regulation No. 24 of 1997 on Land Registration. JURNAL AKTA: Vol. 5, No. 4, 975980. Retrieved from http://jurnal.unissula.ac.id/index.php/akta/article/view/4127

[2] Witasari, Aryani. (2012). MPD Bukan Advokat Para Notaris Berdasarkan UndangUndang Nomor 30 Tahun 2004 tentang Jabatan Notaris, Jurnal Hukum Vol.XXVIII, No 2.

Books:

[1] Adjie, Habib. (2006). Tidak ada sengketa kewenangan antara PPAT dengan Notaris dalam bidang pertanahan. Majalah Renvoi.

[2] Adjie, Habib. (2015). Majelis Pengawas Notaris Sebagai Pejabat Tata Usaha Negara. Bandung: Refika Aditama. 